\title{
PRINSIP DASAR PENERAPAN HUKUMAN DISIPLIN TERHADAP PEGAWAI NEGERI SIPIL
}

\author{
Prista Alisa Ramadhani ${ }^{1}$, Tundjung Herning Sitabuana ${ }^{2}$ \\ ${ }^{1}$ Fakultas Hukum, Universitas Tarumanagara \\ E-mail: prista0602@gmail.com \\ ${ }^{2}$ Dosen Magister Fakultas Hukum, Universitas Tarumanagara Jakarta \\ E-mail: tundjung@fh.untar.ac.id
}

\begin{abstract}
Civil Servants as public servants must be oriented to community satisfaction, it takes ASN who have high integrity and discipline in their duties. Employee discipline must be instilled by every employee. As the embodiment of a government system that wants to achieve national goals, it requires public servants who perform well, have quality, as well as a clean and authoritative government system and create targeted performance so that the implementation is effective and efficient. Work discipline is one of the factors that includes supporting the improvement of employee performance in an organization. In this article, we will discuss the basic principles of imposing disciplinary penalties on Civil Servants. This study uses normative legal research with qualitative analysis through a conceptual approach and a statutory approach to legal issues that are the main problems in the research. This study analyzes how the principle rather than the application of disciplinary punishment to Civil Servants is in accordance with the purpose of the law. PP Disciplinary Civil Servants regulates the principles of applying disciplinary penalties and limiting the authority to impose disciplinary penalties. The success or failure of an organization in realizing its goals by the performance of individual employees.
\end{abstract}

Keywords: Civil Servant, Principle, Disciplinary Punishment.

\begin{abstract}
ABSTRAK
Pegawai Negeri Sipil sebagai pelayan publik harus berorientasi pada kepuasan masyarakat, dibutuhkan ASN yang memiliki integritas tinggi serta disiplin dalam tugas. Disiplin pegawai harus ditanamankan oleh setiap pegawainya. Evaluasi dan pengawasan merupakan cara pemenuhan pelayanan publik terhadap kinerja pegawai. Melalui evaluasi serta dilakukannya pengawasan tersebut diharapkan kinerja PNS dapat menjadi lebih baik dan disiplin. Sebagai perwujudan sistem pemerintahan yang ingin mencapai tujuan nasional, maka dibutuhkan pelayan publik yang berkinerja baik, berkualitas, serta kinerja yang tepat sasaran sehingga dalam pelaksanaannya bersifat efektif dan efisien. Disiplin kerja adalah salah satu faktor yang termasuk penunjang peningkatan kinerja pegawai dalam suatu organisasi. Penelitian ini menggunakan penelitian hukum normatif dengan analisis kualitatif melalui pendekatan konseptual dan pendekatan perundang-undangan terhadap isu hukum yang menjadi pokok permasalahan dalam penelitian. Penelitian ini menganalisis bagaimanakah prinsip dasar daripada penerapan hukuman disiplin terhadap Pegawai Negeri Sipil apakah sesuai dengan tujuan hukum. PP Disiplin PNS mengatur terkait. prosedur, tata cara, dan pembatasan yang diatur dalamnya agar tidak adanya tindakan sewenangnya dalam penjatuhan hukuman disiplin. Berhasil tidaknya suatu organisasi dalam mewujudkan tujuannya dipengaruhi oleh kinerja individu pegawai. Kesimpulan
\end{abstract}

Kata kunci: Pegawai Negeri Sipil, Prinsip, Hukuman Disiplin

\section{PENDAHULUAN}

\section{Latar Belakang}

Indonesia adalah negara hukum, maksud daripada istilah ini adalah bahwa hukum adalah di atas segalanya dan yang berkuasa. Penyelenggaraan aktifitas pun diatur oleh hukum. Kekuasaan pemerintah diatur oleh hukum, bukan tunduk pada negara. Dalam hal ini, unsur daripada negara hukum adalah setiap perorangan terdapat pembatasan kekuasaan negara agar negara memiliki pembatasan terhadap tindakan tanpa bebas melewati kewenangan, tindakan negara dibatasi oleh hukum. Ciri negara hukum kedua adalah adanya asas legalitas, bahwa tindakan negara dibatasi oleh hukum bahwa suatu perbuatan tidak dapat dipertanggungjawabkan apabila belum ada hukum yang mengaturnya. Ciri negara hukum terakhir adalah adanya pemisahaan kekuasaan, 
agar hak asasi setiap manusia dilindungi, maka mewajibkan didalamnya yaitu orang lain termasuk di negaranya untuk menghormatinya. Negara hukum adalah menjamin keadilan terhadap warga negaranya.

Aparatur Sipil Negara (ASN) untuk mencapai tujuan nasional dan mengimplementasikannya berdasarkan Undang-Undang Dasar (UUD) 1945 serta berkinerja baik, bebas dari intervensi politik serta memiliki integritas dan profesional dalam berkinerja sebagaimana dibutuhkan oleh masyarakat untuk terselenggaranya pelayanan publik sesuai yang dibutuhkan masyarakat.

Indonesia adalah negara hukum, sebagaimana dicantumkan dalam hukum dasar di Indonesia, hukum dijadikan sebagai dasar penyelesaian permasalahan hukum. Dengan adanya peraturan hukum sebagai pembatas adanya peristiwa hukum. Peristiwa hukum adalah kejadian yang menggerakkan suatu peristiwa hukum sehingga ketentuan hukum yang terwujud di dalamnya dapat diwujudkan. Sama halnya dengan PNS diatur dengan dengan hukum kepegawaian.

Tatanan kehidupan sehari-hari yang nyata beriringan dengan peraturan-peraturan hukum. Mewujudkan pemerintahan yang baik tentu tidak mudah, harus didukung dengan tindakan pemerintah disesuaikan dengan wewenangnya. Etika dan peran dalam proses administrasi negara adalah hal yang penting sebagai perwujudan pemerintahan yang baik.

Dalam mencapai tujuannya, dimana negara merupakan suatu organisasi kekuasaan, maka pemerintah berada dalam kedudukan yang istimewa. Telah disinggung kalimat kekuasaan dan wewenang, maka keduanya kaitan erat dengan pelaksanaan fungsi pemerintahan. Namun, dalam hal kekuasaan dan wewenang tidak serta dapat melakukan perbuatan yang melanggar, disini fungsi pemerintahan untuk mencapai tujuan pembangunan nasional. Dalam hal turut serta penyelenggaraan pelayanan publik yang tetap berdasar pada hukum yang berlaku. Suatu perbuatan yang dirumuskan agar yang diperintahkan dilakukan dalam bentuk umum maka disebut sebagai hukum. Peraturan hukum sebagai pembatas tatanan kehidupan yang nyata agar setiap subyek hukum tidak melakukan suatu perbuatan dengan sewenang-wenangnya.

PNS merupakan termasuk bagian daripada ASN. Dalam hal ini sebagai penggerak berjalannya pemerintahan agar mencapai tujuan pembangunan nasional, maka selaku PNS harus berkinerja dengan baik dengan cara berorientasi pada hasil dan meningkatkan kualitas diri. Pemerintah haruslah melakukan pelayanan publik yang prima agar dapat menciptakan kepuasan masyarakat. Evaluasi dan pengawasan merupakan cara pemenuhan pelayanan publik terhadap kinerja pegawai. Melalui evaluasi serta dilakukannya pengawasan tersebut diharapkan kinerja PNS dapat menjadi lebih baik dan disiplin. Sebagai perwujudan sistem pemerintahan yang ingin mencapai tujuan nasional, maka dibutuhkan pelayan publik yang berkinerja baik, berkualitas, serta sistem pemerintahan yang bersih dan berwibawa serta menciptakan kinerja yang tepat sasaran sehingga dalam pelaksanaannya bersifat efektif dan efisien. Disiplin kerja adalah salah satu faktor yang termasuk penunjang peningkatan kinerja pegawai dalam suatu organisasi. Berhasil tidaknya suatu organisasi dalam mewujudkan tujuannya dipengaruhi oleh kinerja individu pegawai. Profesional, bertanggungjawab, adil, jujur dan kompeten adalah termasuk faktor pendukung sistem pemerintahan.

Pemerintah berupaya melakukan penataan sistem yang demokratis, transparan dan berwibawa. Upaya pemerintah yaitu dengan cara melakukan penataan aparatur pemerintah. Penataan aparatur pemerintah dalam hal ini Pegawai merupakan alat pemerintah yang diperlukan dalam mewujudkan tujuan nasional pembangunan. Terwujudnya disiplin apabila masing-masing pegawai dapat memahami evaluasi kinerjanya serta pembatasan atas perbuatan yang diatur dalam peraturan pemerintah ini. Penerapan disiplin jika telah dilaksanakan dengan baik pada organisasi maka menciptakan iklim kinerja yang teratur dan tertib.

Sebelumnya peraturan tentang disiplin PNS diatur dalam Peraturan Pemerintah Nomor 53 tahun 2010 (PP 53 tahun 2010). Sehingga ada penyesuaian terhadap perkembangan zaman, maka akhir Agustus 2021 dikeluarkan peraturan terbaru yaitu Peraturan Pemerintah Nomor 94 tahun 2021 
tentang Disiplin Pegawai Negeri Sipil (PP 94 tahun 2021). Agar terjamin terpeliharanya pelaksanaan tugas serta mencapai tujuan organisasi dan kinerja baik yang harapannya dapat diperoleh oleh setiap pegawai, maka PNS diwajibkan mematuhi peraturan hukum terkait dengan pelaksanaan kesehariannya yaitu Disiplin PNS. Tujuan dibentuknya peraturan ini agar terciptanya pembinaan bagi pegawai yang melakukan pelanggaran, sebagai pengatur aktifitas pegawai agar tidak melakukan pelanggaran, dan adanya sanksi hukum. Pada dasarnya pembuatan hukum dimulai dari sebuah gagasan atau ide kemudian dibentuklah suatu undangundang dan pada akhirnya terdapat sanksi hukum agar terciptanya ketertiban dalam pelaksanaan pelayanan publik. Terlepas dari apa yang ada dalam menjalankan organisasi, peran setiap pegawai yang dapat memajukan potensi kemajuan suatu organisasi. Keberhasilan daripada organisasi bergantung pada peran manusia maka dibutuhkan kedisiplinan.

Berikut adalah tabel penegakan hukuman disiplin terhadap PNS di lingkungan Kementerian Hukum dan HAM tahun 2021 yang disesuaikan dengan PP 53 tahun 2010 tentang Disiplin PNS sebelum dikeluarkannya PP 94 tahun 2021 tentang Disiplin PNS:

Table 1 .Jenis Hukuman Disiplin Periode Jan-Juli 2021 di Lingkungan Kementerian Hukum dan HAM

\begin{tabular}{clc}
\hline NO & \multicolumn{1}{c}{ SURAT KEPUTUSAN } & JUMLAH \\
\hline 1 & Hukdis Ringan Teguran Tertulis & 2 \\
\hline 2 & Turun pangkat setingkat lebih rendah selama 1 tahun & 1 \\
\hline 3 & Turun pangkat setingkat lebih rendah selama 3 tahun & 4 \\
\hline 4 & Bebas dari jabatan & 68 \\
\hline 5 & $\begin{array}{l}\text { Hukdis Berat Pemberhentian dengan hormat tidak atas permintaan } \\
\text { sendiri }\end{array}$ & 1 \\
\hline 6 & $\begin{array}{l}\text { Hukdis Berat Pemberhentian dengan hormat tidak atas permintaan } \\
\text { sendiri karena tindak pidana }\end{array}$ & 17 \\
\hline 7 & Pemberhentian Tidak Dengan Hormat Karena Tindak Pidana & 4 \\
\hline 8 & $\begin{array}{l}\text { Pemberhentian Sebagai CPNS karena tindak pidana } \\
\text { Pemberhentian Sementara Sebagai Pegawai Negeri Sipil Yang } \\
\text { Ditahan } \\
\text { Karena Menjadi Tersangka Tindak Pidana }\end{array}$ & $\begin{array}{l}\text { Pemberhentian Sebagai CPNS dan Tidak Boleh Mengikuti Seleksi } \\
\text { PengadaanPNS Untuk Jangka Waktu Tertentu }\end{array}$ \\
\hline \multicolumn{1}{c}{ TOTAL } & $\mathbf{1 1 3}$ \\
\hline
\end{tabular}

Berdasarkan hal tersebut di atas, maka akan dibahas prinsip penerapan penjatuhan hukuman disiplin terhadap PNS disesuaikan dengan aturan terbaru yaitu PP 94 tahun 2021 tentang Disiplin PNS. Penulis tertarik membahas prosedur, tata cara, dan pembatasan yang diatur dalamnya terkait dengan disiplin pegawai dan pembatasan kewenangan.

\section{Rumusan Masalah}

Dengan dibahasnya latar belakang diatas maka masalah yang teridentifikasi adalah sebagai berikut: Bagaimana prinsip dasar penerapan hukuman disiplin sebagaimana diatur dalam PP 94 tahun 2021 tentang Disiplin PNS? 


\section{METODE PENELITIAN}

Menurut Soetandyo Wignjosoebroto, penelitian memiliki makna sebagai pencarian. Apabila didefinisikan penelitian memiliki arti suatu kegiatan yang disengeja, memiiki tujuan, dan memiliki prosedur atau metode. Pencarian atau penelitian dapat dilakukan secara spekulatif untuk mendapatkan suatu kesimpulan atau dapat dilakukan secara terus-menerus. Spesifikasi dalam penelitian yang ditulis ini bersifat deskriptif analitis, yakni menjabarkan penelitian dan hasil diperoleh dengan menggunakan pendekatan kualitatif yang hasilnya berupa analisis berupa observasi dan wawancara. Alasan penulis menggunakan jenis penelitian ini karena dilakukan dengan cara menganalisa undang-undang dan meneliti bahan kepustakaan. Penelitian disini adalah penelitian hukum normative yang didasarkan pada Analisa terhadap norma hukum dan melakukan kajian terhadap peraturan perundang-undangan. Penelitian ini didapatkan juga berdasarkan data lapangan di lingkungan Kementerian Hukum dan HAM, Jakarta sebagai pelengkap untuk mendukung analisis penelitian ini.

\section{Kerangka Teori}

\section{Penerapan Asas Umum Pemerintahan yang Baik (AUPB)}

AUPB sebagai dasar pembentukan kaidah hukum sebagai dasar untuk mengatur perlakuan dalam lapangan hukum tata pemerintahan. AUPB sebagai pedoman penyelenggaraan urusan pemerintahan, dikarenakan AUPB ini juga sebagai pertimbangan dasar sah atau tidaknya suatu Keputusan dimana harus selaras dengan UU dan AUPB. Jika prinsip AUPB diabaikan maka Keputusan dapat digugat keabsahannya. Salah satu AUPB adalah asas kepastian hukum, karena dalam menilai aspek materiil daripada suatu Keputusan sebagai prinsip yang penting.

\section{Freies Ermessen dalam Hukum Administrasi Negara}

Maksud daripada freis ermessen adalah negara memberikan kebebasan untuk bertindak melakukan suatu perbuatan atas inisiatif sendiri kepada administrasi negara guna penyelesaian kepentingan umum. Tujuannya adalah kesejahteraan umum atas Keputusan dari administrasi negara. Freies Ermessen dalam Administrasi negara berpijak pada asas kebijaksanaan. Dalam hal kalimat inisiatif sendiri, bukan berarti mengesampingkan asas legalitas namun diuji berdasarkan peraturan perundang-undangan dan hukum tidak tertulis.

\section{Pembatasan Kewenangan Pemerintahan}

Penggunaan wewenang pemerintahan perlu dibatasi agar tidak adanya penyalahgunaan kewenangan dan melanggar aturan hukum. Aminuddin Ilmar mengemukakan bahwa kepentingan membatasi wewenang sebagai dasar melakukan tindakan agar perbuatan tidak disalahgunakan atau menyimpang dari wewenang pemerintahan yang diberikan kepadanya (Alamsah, 2019). Adanya wewenang sebagai landasan legalitas daripada tindakan pemerintahan. Tindakan dan wewenang saling keterkaitan atas perbuatan pemerintah dan berdasar pada kewenangan yang sah.

\section{HASIL DAN PEMBAHASAN}

Prinsip Dasar Penerapan Hukuman Disiplin Sebagaimana Diatur Dalam Peraturan Pemerintah Nomor 94 Tahun 2021 tentang Disiplin Pegawai Negeri Sipil

Pada prinsipnya semua ingin memiliki pegawai yang tertib, rajin dan disiplin untuk tercapainya tujuan daripada suatu organisasi. Namun, cara untuk mencapai tujuan organisasi tersebut yang kurang diperhatikan sehingga hanya hasilnya saja yang diperhatikan. Cara agar mencapai tujuan daripada organisasi yaitu berawal dari perbaikan sumber daya manusia itu sendiri. PP 94 tahun 2021 dikeluarkan agar terjaminnya tata tertib pelaksanaan tugas sebagai ASN, selain itu, pengaturan tentang kewenangan penjatuhan hukuman disiplin terhadap pegawai agar tidak 
adanya perbuatan yang melsampai pada pemberlakuan hukuman disiplin dan pendokumentasian Keputusan.

Berdasarkan peraturan tentang disiplin PNS didalamnya menyebutkan bahwa disiplin adalah menghindari larangan dan menaati kewajiban agar terciptanya tata tertib pelaksanaan tugas. Berikut adalah tingkat dan jenis hukuman disiplin sebagaimana diatur dalam Pasal 8 PP 94 tahun 2021:

a. Hukuman disiplin ringan;

b. Hukuman disiplin sedang; atau

c. Hukuman disiplin berat.

Jenis hukuman disiplin ringan terdiri atas:

a. Teguran lisan;

b. Teguran tertulis; atau

c. Pernyataan tidak puas secara tertulis.

Jenis hukuman disiplin sedang terdiri atas:

a. Pemotongan tunjangan kinerja sebesar $25 \%$ (dua puluh lima persen) selama 6 (enam) bulan;

b. Pemotongan tunjangan kinerja sebesar $25 \%$ (dua puluh lima persen) selama 9 (sembilan) bulan; dan

c. Pemotongan tunjangan kinerja sebesar $25 \%$ (dua puluh lima persen) selama 12 (dua belas) bulan.

Jenis hukuman disiplin berat terdiri atas:

a. Penurunan jabatan setingksat lebih rendah selama 12 (dua belas) bulan;

b. Pembebasan dari jabatannya menjadi jabatan pelaksana selama 12 (dua belas) bulan; dan

c. Pemberhentian dengan hormat tidak atas permintaan sendiri sebagai PNS.

Pelanggaran disiplin bukanlah termasuk delik aduan. Apabila terdapat dugaan suatu perbuatan yang tidak sesuai maka atasan langsung dapat bertindak untuk mempertanggungjawabkan kinerja bawahannya dan melakukan tindakan sebagaimana diatur dalam PP 94 tahun 2021 yaitu pemeriksaan. Perbuatan yang dilakukan oleh pegawai yang tidak sesuai bukanlah termasuk delik aduan. Mengapa bukan termasuk delik aduan? Karena merupakan tanggung jawab oleh atasan langsung apabila sudah ada dugaan pelanggaran disiplin. Dalam hal pelanggaran berupa absensi maupun pelanggaran lainnya yang disebutkan dalam PP 94 tahun 2021, maka atasan langsung dapat melakukan pemeriksaan, namun, apabila perbuatan tersebut bukan merupakan kewenangan atasan langsung maka dilaporkan secara berjenjang untuk ditindaklanjuti Keputusannya. Laporan tersebut dibuktikan dengan lengkap yaitu dengan melampirkan Berita Acara Pemeriksaan (BAP) dan Laporan Hasil Pemeriksaan (LHP).

Badan atau pejabat pemerintahan tidak bisa bertindak sewenang-wenangnya perihal menjatuhkan hukuman disiplin, harus disesuaikan dengan aturan bahwa yang bersangkutan mempunyai kewenangan. Tujuannya adalah agar tidak melanggar AUPB yaitu asas tidak menyalahgunakan wewenang. Prosedur penjatuhan hukuman disiplin pun tidak mudah untuk dikeluarkan suatu Keputusan namun harus berdasarkan aturan hukum dan AUPB.

Kewenangan untuk menetapkan hukuman disiplin sudah tercantum dalam peraturan ini agar tidak adanya tindakan sewenang-wenangnya terhadap penetapan hukuman disiplin. Sebelum ditetapkannya hukuman disiplin, pegawai yang melanggar diperiksa terlebih dahulu dengan tanpa adanya paksaan sedikitpun, dalam hal kelancaran pemeriksaan apabila pegawai diduga melakukan pelanggaran disiplin yang termasuk dalam jenis hukuman disiplin tingkat berat maka pegawai dapat dibebaskan sementara dari tugas jabatannya selama dilakukan pemeriksaan sampai dikeluarkannya Keputusan Hukuman Disiplin. Dalam hal atasan langsung yang tidak menindaklanjuti dugaan pelanggaran terhadap bawahannya yaitu dengan tidak melakukan apa yang diatur dalam peraturan pemerintah dengan cara melakukan pemanggilan dan pemeriksaan maka atasan langsung menerima hukuman yang lebih berat. 
Implementasi terhadap sanksi pegawai berupa penjatuhan hukuman tingkat ringan dan berat disesuaikan dengan PP 94 tahun 2021, namun ada pembeda terkait hukuman disiplin tingkat sedang. Pemberlakuan jenis hukuman disiplin tingkat sedang belum mulai berlaku dalam peraturan pemerintah ini, karena peraturan pemerintah terkait gaji dan tunjangan belum berlaku. Penjatuhan hukuman disiplin tingkat sedang masih berdasar peraturan lama yaitu PP 53 tahun 2010.

\section{KESIMPULAN DAN SARAN}

Pada prinsipnya semua ingin memiliki pegawai yang tertib, rajin dan disiplin untuk tercapainya tujuan daripada suatu organisasi. Cara agar mencapai tujuan daripada organisasi yaitu berawal dari perbaikan sumber daya manusia itu sendiri. Berdasarkan PP 94 tahun 2021 pada prinsipnya peraturan terkait Disiplin PNS dibuat untuk mengatur tingkah laku pegawai serta pejabat agar adanya pembatasan dalam penerapan penjatuhan hukuman disiplin. Pelanggaran disiplin bukanlah merupakan delik aduan. Atasan langsung yang bertanggungjawab atas tindakan pegawainya apabila diduga melakukan pelanggaran disiplin.

Adapun saran sebagaimana diketahui bahwa PNS sebagai subyek daripada pemerintahan, maka untuk mencapai tujuan nasional daripada sistem pemerintahan dibutuhkan sanksi yang lebih tegas terhadap pelanggaran disiplin. Pemahaman disiplin PNS ini sangat diperlukan agar mencapai PNS yang lebih produktif berdasarkan sistem prestasi dan sistem karier. Dalam media social semestinya lebih massif lagi dalam hal peraturan disiplin ini agar menjadi pedoman PNS untuk menghindari larangan dan mematuhi kewajiban.

\section{Ucapan Terima Kasih}

Puji syukur penulis panjatkan kepada Allah SWT atas semua penyertaan-Nya sehingga penulis dapat memperoleh rahmat dan kebijaksanaan untuk menyelesaikan jurnal ini.

Jurnal yang berjudul "Prinsip Dasar Penerapan Hukuman Disiplin Terhadap Pegawai Negeri Sipil", disusun oleh penulis sebagai salah satu penilaian mata kuliah Teori Hukum.

Penulis pun mengucapkan terima kasih kepada:

1. Biro Kepegawaian Sekretariat Jenderal Kementerian Hukum dan HAM

2. Lembaga Penelitian dan Pengabdian Kepada Masyarakat Universitas Tarumanagara yang telah merealisasikan SENAPENMAS 2021.

\section{REFERENSI}

Alamsah, Nandang. (2018). Teori \& Praktek Kewenangan Pemerintahan. Unpad Press, Sumedang.

Darna, Nana \& Elin Herlina. (2018). "Memilih Metode Penelitian yang Tepat: Bagi Penelitian Bidang Ilmu Manajemen”. Jurnal Ilmu Manajemen., 5 (1), 288.

Hakim, Arief Rachman. (2018). Perlindungan Hukum Undang-Undang Nomor 30 Tahun 2014 Bagi PNS yang Diberhentikan dan Implikasinya terhadap Kewenangan Badan Pertimbangan Kepegawaian. Jurnal Dinamika Hukum., 4 (2), 988.

Hartini, Sri. (2011). Upaya Keberatan Terhadap PNS yang Dijatuhi Hukuman Pemberhentian Tidak Dengan Hormat, Jurnal Dinamika Hukum., 11(2), 360.

Isharyanto. (2016). Teori Hukum Suatu Pengantar dengan Pendekatan Teknik. WR Penerbit, Jakarta.

Komara, Endang. (2019). Kompetensi Profesional Pegawai ASN di Indonesia. Mimbar Pendidikan: Jurnal Indonesia untuk Kajian Pendidikan., 4(1), 74.

Marzuki, Peter Mahmud, (2005). Penelitian Hukum Edisi Revisi. PT Kharisma Putra Utama: Surabaya. 


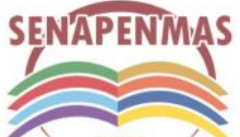

2021
Seminar Nasional Hasil Penelitian dan Pengabdian Kepada Masyarakat 2021

Pengembangan Ekonomi Bangsa Melalui Inovasi Digital Hasil Penelitian dan Pengabdian Kepada Masyarakat Jakarta, 21 Oktober 2021

Panjaitan. Saut. (2016). Makna dan Peranan Freies Ermessen dalam Hukum Administrasi Negara. UNISIA, 10 (IV), hlm. 55

Rahardjo, Satjipto. (2014). Ilmu Hukum. PT. Citra Aditya Bakti: Bandung.

Rahayu, Eva Afriana, (2021). Disiplin Kerja dan Kinerja ASN di Kantor Dinas Pendidikan Kabupaten Luwu Timur. Retrieved September 6, 2021, from http://eprints.unm.ac.id/15375/1/JURNAL\%20EVA\%20AFRIANA.pdf

Republik Indonesia. Undang-Undang Nomor 5 Tahun 2014 tentang Aparatur Sipil Negara Peraturan Pemerintah Nomor 94 Tahun 2021 tentang Disiplin Pegawai Negeri Sipil

Peraturan Pemerintah Nomor 53 Tahun 2010 tentang Disiplin Pegawai Negeri Sipil 
Seminar Nasional Hasil Penelitian dan Pengabdian Kepada Masyarakat 2021

Pengembangan Ekonomi Bangsa Melalui Inovasi Digital Hasil Penelitian dan

Pengabdian Kepada Masyarakat

Jakarta, 21 Oktober 2021

(halaman kosong) 